\title{
Evaluation of the cytotoxicity of selected conventional glass ionomer cements on human gingival fibroblasts
}

\author{
Grażyna Marczuk-Kolada ${ }^{1, A-D}$, Elżbieta Łuczaj-Cepowicz ${ }^{1, B-D}$, Małgorzata Pawińska ${ }^{2, C-E}$, Adam Hołownia 3, A, B, F \\ ${ }^{1}$ Department of Pedodontics, Medical University of Bialystok, Poland \\ ${ }^{2}$ Department of Conservative Dentistry, Medical University of Bialystok, Poland \\ ${ }^{3}$ Department of Clinical Pharmacology, Medical University of Bialystok, Poland \\ A - research concept and design; B - collection and/or assembly of data; C - data analysis and interpretation; \\ $D$ - writing the article; $E$ - critical revision of the article; $F$ - final approval of article
}

\section{Address for correspondence \\ Grażyna Marczuk-Kolada}

E-mail: grazyna.kolada@umb.edu.pl

Funding sources

None declared

Conflict of interest

None declared

Received on March 4, 2015

Revised on March 24, 2015

Accepted on April 24, 2015

\begin{abstract}
Background. Dentistry materials are the most frequently used substitutes of human tissues. Therefore, an assessment of dental filling materials should cover not only their chemical, physical, and mechanical characteristics, but also their cytotoxicity.

Objectives. To compare the cytotoxic effects of 13 conventional glass ionomer cements on human gingival fibroblasts.

Material and methods. The assessment was conducted using the MTT test. Six samples were prepared for each material. Culture plates with cells and inserts with the materials were incubated at $37^{\circ} \mathrm{C}, 5 \%$ $\mathrm{CO}_{2}$, and $95 \%$ humidity for $24 \mathrm{~h}$. Then the inserts were removed, $1 \mathrm{~mL}$ of MTT was added in the amount of $0.5 \mathrm{mg} / 1 \mathrm{~mL}$ of the medium, and the samples were incubated in the described conditions without light for $2 \mathrm{~h}$. The optical density was measured with an absorption spectrophotometer at a wavelength of $560 \mathrm{~nm}$.

Results. The cytotoxic effects of the Argion Molar was significantly stronger than the Fuji Triage $(p=0.007)$, Chemfil Molar $(p<0.0001)$, and lonofil Molar AC Quick ( $p<0.001)$. The Fuj IX GP and Fuj IX Extra had a significantly stronger adverse effect than the Chemfil Molar ( $p=0.014, p=0.029$, respectively) and lonofil Molar AC Quick ( $p=0.017, p=0.034$, respectively). The cements from the low cytotoxicity group were significantly more toxic vs materials whose presence resulted in fibroblast growth $(p<0.001)$.

Conclusions. The research conducted indicates that, although the materials studied may belong to the same group, they are characterized by low, yet not uniform, cytotoxicity on human gingival fibroblasts. The toxic effects should not be assigned to a relevant group of materials, but each dentistry product should be evaluated individually.
\end{abstract}

Key words: dentistry, fibroblasts, glass ionomer cements

DOI

10.17219/acem/64944

Copyright

Copyright by Author(s)

This is an article distributed under the terms of the

Creative Commons Attribution Non-Commercial License

(http://creativecommons.org/licenses/by-nc-nd/4.0/) 
Due to developments in science and technology, there are numerous products for the reconstruction of tooth tissues currently available on the dentistry market. According to Tilberg et al., dentistry materials are the most frequently used substitutes of human tissues. ${ }^{1}$ They can affect surrounding structures either directly or indirectly when substances released by the fillings migrate through dentin channels into the pulp during the curing process and/or after it is completed. Therefore, the assessment of dental filling materials should cover not only their chemical, physical and mechanical characteristics, but also their biocompatibility, which is understood as a material's ability to function in live organisms and induce the appropriate tissue response. ${ }^{2,3}$ Its measures include cytotoxicity, that is, the effect of a studied material on cell viability. ${ }^{2}$ Cytotoxicity is a complex process, as there are numerous mechanisms causing functional and structural changes in cells and tissues. ${ }^{2,4}$

Glass ionomer cements were launched in the dentistry market in the 1970 s. $^{5-8}$ Their composition was based on fluoroaluminosilicate glass and a liquid part, usually a water solution of polyalkenoic acid. ${ }^{5-8}$ Unfortunately, because of their disadvantages, including low mechanical strength, long setting time and high sensitivity to moisture at the beginning of curing, the first products from this group were criticized by clinicians. ${ }^{5-8}$ However, these materials had some indisputable advantages: chemical adhesion to mineralized tooth tissues, remineralization and antibacterial properties. ${ }^{5-8}$ For these reasons, conventional glass ionomer cements (GIC) have been modernized. They are widely used in dentistry, particularly as materials for reconstructing missing hard tissues in deciduous teeth.

Literature data on the biocompatibility of glass ionomer cements is inconsistent. ${ }^{9}$ Many authors suggest their high biocompatibility. ${ }^{10-13}$ However, there are reports noting an adverse effect of these materials on live cells. ${ }^{14-16}$ Differences in the results obtained by researchers may result from variability in research protocols. ${ }^{17,18}$ For this reason, the aim of our study was to compare the cytotoxicity of currently available conventional glass ionomer cements in identical conditions and to verify contradictory reports on their biocompatibility.

\section{Material and methods}

\section{Material sample preparation}

The test was conducted for 13 conventional glass ionomer materials (GIC), including 2 reinforced with silver (MGIC) in color A3 (Table 1).

The cements studied were packed in capsules. They were prepared immediately before the test, in sterile conditions, using a crusher and shaker as specified by the manufacturer. The prepared materials were applied into plastic rings
Table 1. Materials tested in the study

\begin{tabular}{|c|c|c|}
\hline Material & Manufacturer & Lot \\
\hline Argion Molar & $\begin{array}{c}\text { VOCO GmbH, Cuxhaven, } \\
\text { Germany }\end{array}$ & 0936172 \\
\hline Fuji IX GP & GC Corp., Tokyo, Japan & 0904201 \\
\hline Fuji IX Extra & GC Corp., Tokyo, Japan & 0904211 \\
\hline Riva Silver & SDI Ltd., Bayswater, Australia & G1005031 \\
\hline Fuji IX Fast & GC Corp., Tokyo, Japan & 0812174 \\
\hline Fuji Triage & GC Corp., Tokyo Japan & 0806051 \\
\hline Chemfil Molar & $\begin{array}{c}\text { DENTSPLY De Trey GmbH, } \\
\text { Kostanz, Germany }\end{array}$ & 0817100 \\
\hline Ionofil Molar AC Quick & $\begin{array}{c}\text { VOCO GmbH, Cuxhaven, } \\
\text { Germany }\end{array}$ & 0912304 \\
\hline Ketac Silver & 3M ESPE AG, Seefeld, Germany & 328538 \\
\hline Ketac Molar Aplicap & 3M ESPE AG, Seefeld, Germany & 366335 \\
\hline Riva SC & SDI Ltd., Bayswater, Australia & A1004292 \\
\hline Ketac Molar Quick & 3M ESPE AG, Seefeld, Germany & 387995 \\
\hline Ketac Fil Plus Aplicap & 3M ESPE AG, Seefeld, Germany & 365422 \\
\hline
\end{tabular}

of $5 \mathrm{~mm}$ (inner diameter) $\times 5 \mathrm{~mm}$ (height). The rings with the materials were placed in inserts (Nunc GmbH\&Co KG, Wiesbaden, Germany), of a surface area of $0.47 \mathrm{~cm}^{2}$ and pore diameter of $0.4 \mu \mathrm{m}$, which were located in 24-well culture plates (Nunc GmbH\&Co KG, Wiesbaden, Germany) containing human gingival fibroblasts. Six samples were prepared for each material. Six wells with inserts without any material constituted the control.

\section{Cell culture preparation}

Human gingival fibroblasts from the adherent permanent cell line (ATCC ${ }^{\circledR}$ CRL-2014HGF-1 (LGC Promochem, Warszawa, Poland) were grown in Falcon containers (growth area of $75 \mathrm{~cm}^{2}$ ) on DMEM (Dulbecco's Modified Eagle's Medium) (Gibco, Warszawa, Poland) with 10\% fetal bovine serum (FBS) (Gibco, Warszawa, Poland) added, at $37^{\circ} \mathrm{C}, 5 \% \mathrm{CO}_{2}$, and $95 \%$ humidity. When the confluent growth was obtained, the cells were incubated with $0.25 \%$ trypsin solution with 0.53 mM EDTA added. Then, a medium with $10 \%$ FBS was added to inhibit enzyme activity. The cell suspension diluted in a fresh medium was inoculated in 24-well plates and incubated for $24 \mathrm{~h}$.

\section{Cytotoxicity evaluation}

The cytotoxicity of the materials studied was evaluated using the MTT test. It is an indirect method determining cell viability and proliferation on the basis of mitochondrial succinate dehydrogenase activity. In live cells, this enzyme reduces yellow tetrazole salt, 
3-(4,5-dimethyl-2-thiazolyl)-2,5-diphenyl-2H-tetrazolium bromide, to formazan precipitating as insoluble grey-purple crystals. The intensity of the solution color after dissolving the crystals, measured by a spectrophotometer, is a measure of cell viability. For low cell survival, low enzymatic activity is found resulting in a low content of purple formazan and lower optical density values.

The culture plates with the cells and applied materials were incubated at $37^{\circ} \mathrm{C}, 5 \% \mathrm{CO}_{2}$, and $95 \% \mathrm{hu}-$ midity for $24 \mathrm{~h}$. Then, the inserts with the materials were removed, and $1 \mathrm{~mL}$ of medium containing 3-(4,5-dimethyl-2-thiazolyl)-2,5-diphenyl-2H-tetrazolium bromide (MTT) was added to each well at a level of $0.5 \mathrm{mg} /$ $\mathrm{mL}$, and the plates were incubated without light in the conditions described above for $3 \mathrm{~h}$. Afterwards, the fluid was aspirated from the culture, and $1 \mathrm{~mL}$ of isopropanol acidified with hydrochloric acid was added. To dissolve the formazan crystals, the solution obtained was stirred for a short time. The optical density (OD) was measured with a double-beam absorption spectrophotometer Lambda EZ 2001 (Perkin Elmer, Waltham, USA) at a wavelength of $560 \mathrm{~nm}$. Cell viability was calculated using the following formula: [mean OD of test group/mean OD of control group] $\times 100 \%$.

Cell viability was scored according to the method by da Silva et al. ${ }^{19}$ If cell viability exceeded $90 \%$, the material was deemed non-cytotoxic. For cell viability at the 60-90\% range, the material was regarded as slightly cytotoxic. For cell viability at the $30-59 \%$ range, the material was regarded as moderately cytotoxic. For cell viability below $30 \%$, the material was considered severely cytotoxic.

\section{Statistical analysis}

The statistical analysis was performed using the STATISTICA v. 8.0 (StatSoft Sp. z o.o., Kraków, Poland) software package. For comparisons between the groups, the one-way analysis of variance ANOVA and post hoc Tukey's HSD (honestly significant difference) tests were used. The hierarchical cluster analysis with a dendrogram, using the average linkage between groups, was used as the classification method. The level of significance was set at $\mathrm{p}<0.05$.

\section{Results}

None of the 13 materials exhibited high or medium cytotoxicity. In all cases, fibroblast survival exceeded $60 \%$. The group with low cytotoxicity consisted of 4 glass ionomer cements: conventional - Fuji IX GP and Fuji IX Extra; and silver-reinforced - Argion Molar and Riva Silver. Other materials studied had no adverse effects. More than $90 \%$ of fibroblasts survived in the presence of Fuji IX Fast, Fuji Triage, Chemfil Molar, and Ionofil Molar AC Quick; while in the vicinity of Ketac Silver, Ketac Molar
Fig. 1. Mean cell viability ratios and standard deviations of the materials tested

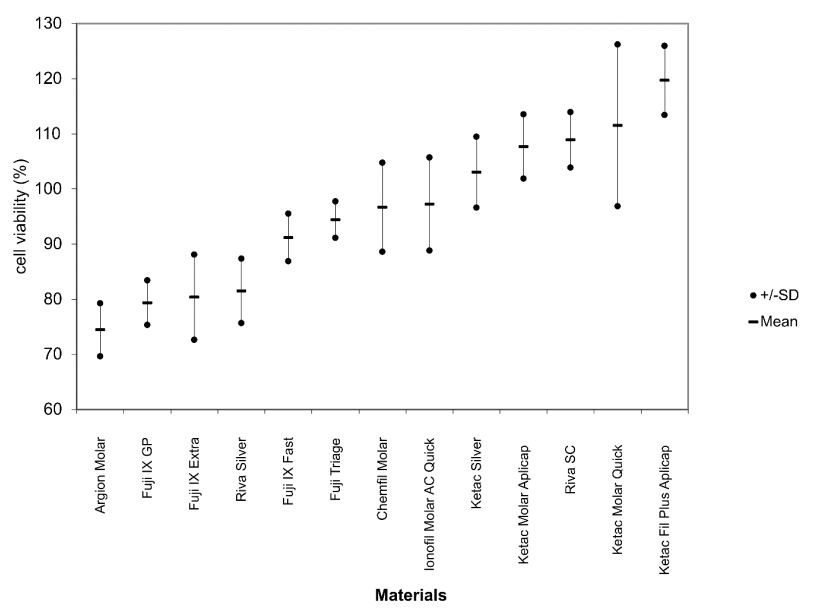

Aplicap, Riva SC, Ketac Molar Quick, and Ketac Fil Plus Aplicap, they multiplied.

One-way variance analysis indicated significant differences in cell survival with different materials ( $\mathrm{p}<0.001)$. Assessment with Tukey's post hoc test showed that the effect of materials with low cytotoxicity did not differ significantly. A similar relationship applied to the group of materials without an adverse effect on fibroblasts.

Significant differences were found between materials from different groups (Fig. 1).

The cytotoxic effect of Argion Molar was significantly stronger than Fuji Triage $(\mathrm{p}=0.007)$, Chemfil Molar ( $\mathrm{p}<0.0001)$ and Ionofil Molar AC Quick ( $<<0.001)$. Fuji IX GP and Fuji IX Extra had a significantly stronger adverse effect than Chemfil Molar $(\mathrm{p}=0.014$ and $\mathrm{p}=0.029$, respectively) and Ionofil Molar AC Quick ( $p=0.017$ and $\mathrm{p}=0.034$, respectively). Cements from the low cytotoxicity group were significantly more toxic vs materials whose presence resulted in fibroblast growth $(\mathrm{p}<0.001)$.

The dendrogram (Fig. 2) presents three separate clusters of materials that are most similar to each other in terms of cell survival ratio in the culture.

The tested materials with the most similar cytotoxicity are connected by vertical lines and form a cluster. The position of the lines on the scale (at the top of the figure) indicates the distances between clusters: the closer to the scale center, the greater similarity in cytotoxicity.

Fig. 2. Similarities in the toxic effect of the materials examined

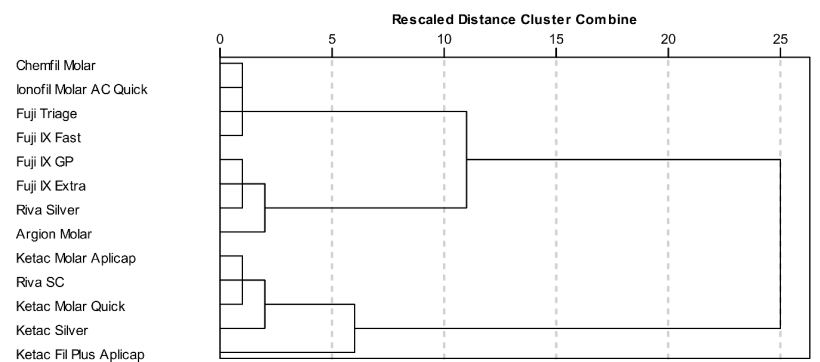


We found the greatest similarity in effects on the viability of fibroblasts in the following groups: Chemfil Molar (96.7\%), Ionofil Molar AC Quick (97.2\%), Fuji Triage (94.4\%) and Fuji IX Fast (91.2\%) in the first cluster; the second cluster - Fuji IX GP (79.4\%), Fuji IX Extra (80.4\%), Riva Silver (81.5\%); and the third cluster consisted of Ketac Molar Aplicap (107.7\%), Riva SC (108.9\%), Ketac Molar Quick (111.5\%), and Ketac Silver (103.0\%).

\section{Discussion}

Studies evaluating the biological characteristics of dentistry materials have been conducted for many years. They have used various methods, including in vitro tests on cell cultures, pre-clinical studies on laboratory animals and clinical trials in patients. ${ }^{2-4}$ The use of animals for biocompatibility assessments of dentistry materials represents an ethical problem and has been widely debated. For this reason, the International Organization for Standardization (ISO) recommends in vitro studies with cell cultures and limiting tests conducted on animal models.

Cytotoxic activity can be determined using various laboratory tests. The MTT test is recommended by ISO as a reference, and was used in our experiment. It determines the activity of succinate dehydrogenase, a mitochondrial enzyme present in live cells. ${ }^{19}$

Selection of an appropriate cell line is a very important part of the study during in vitro cytotoxicity assessments. Researchers' opinions on that issue vary. The use of permanent, standard cell lines or primary cells collected from gingiva, periodontium or the pulp is recommended. Permanent cell lines are morphologically and physiologically uniform. Primary cells represent clinical conditions better, but are diversified and have lower viability. ${ }^{20}$ TheISO 10993 standard, standardizing in vitro studies, supports the use of permanent cell lines. ${ }^{2,4,12}$ In our study, we used a standard human gingiva fibroblast line; and to reproduce conditions similar to clinical, we placed samples of materials on a semi-permeable membrane of inserts.

The study conducted indicates that the evaluated materials were characterized by low or lack of cytotoxicity. Schedle et al. obtained completely different results. ${ }^{16}$ Using a flow cytometry method, the authors compared the cytotoxicity of various dentistry materials, including 2 conventional glass ionomer cements. On the basis of the study results, they suggested that for the evaluated cements, the adverse effects on fibroblasts were comparable to the effect of composite materials considered to be very cytotoxic. An unfavorable opinion on the biological characteristics of glass ionomer cements was presented in the study by Milhem et al. ${ }^{14}$ They conducted an experiment using Artemia Salina larvae exposed to alcohol eluates of the assessed materials. The results indicated that Ketac Fil cement was more toxic than the composite materials.
In a majority of the published studies, the authors evaluating the biological effects of conventional glass ionomer cements showed that they were characterized by low cytotoxicity. ${ }^{10-13}$ The results of our study are consistent with that finding. The group with low toxicity contained 4 materials: Argion Molar and Riva Silver (conventional glass ionomer cements reinforced with silver), and Fuji IX GP and Fuji IX Extra, differing significantly from the remaining 9 products.

The reasons for the cytotoxicity of the evaluated preparations have not been sufficiently explained. The literature contains various interpretations of this phenomenon. The authors emphasize the effect of low $\mathrm{pH}$ during setting and the effects of various released components. ${ }^{17,21-23}$ Migration of certain ions is most often mentioned. The release of fluoride ions from glass-ionomer cements is commonly known.

Kan et al. investigated the cytotoxicity and fluoride release of 2 resin-modified GICs, a conventional glass-ionomer cement, and a resin composite. ${ }^{24}$ Fluoride release and cytotoxicity were correlated, although the fluoride release did not account for the cytotoxicity observed. In their opinion, there were factors other than fluoride responsible for the cytotoxicity. According to Wilson et al., the following ions are released from conventional glass-ionomer cements: $\mathrm{F}, \mathrm{Na}$ and $\mathrm{Si}^{25}$ Recent studies by Nicholson et al. have also demonstrated the release of $\mathrm{Al}, \mathrm{P}$, and $\mathrm{Ca}$, depending on the $\mathrm{pH}$ solution. ${ }^{26}$ The effect of different ions on the cytotoxicity of these materials is still unclear. In the authors' opinion, ions, apart from aluminum, are acceptable in the body and useful for a variety of physiological processes. ${ }^{26}$ However, the total amount of aluminum released from glass-ionomer cements is so low that this is not a significant problem. ${ }^{27}$ As indicated by Forss, ${ }^{28}$ the ion amount leached to the environment is associated with the material's composition. In Tyas' opinion, contemporary glass-ionomer cements consist of fluoroaluminosilicate glass, usually a strontium or calcium salt, and polyalkenoic acid liquid, for example polyacrylic, maleic, itaconic, and tricarballylic acids. ${ }^{6}$ The exact chemical compositions of the materials are not provided by the manufacturers.

Stanisławski et al. studied the cytotoxic effects of several ions released from different materials. ${ }^{23}$ That study indicates that the $\mathrm{F}^{-}, \mathrm{Al}^{3+}$ and $\mathrm{Sr}^{2+}$ levels were too low to damage cultured cells. In these authors' opinion, the main factors responsible for cytotoxicity were the presence of copper and silver ions in the case of HiDense - a conventional glass ionomer cement reinforced with silver. In our experiment, we did not study ion release, but the cytotoxicity of Argion Molar and Riva Silver may be related to a similar mechanism.

The studies by Stanisławski et al. and Soheili Majd et al. expanded our knowledge on biochemical mechanisms underlying the cytotoxicity of glass ionomer cements. ${ }^{15,29}$ The above-mentioned authors proved that Fuji II and 
Ketac Fil Plus Aplicap caused a reduction in cellular glutathione (GSH), one of the most important antioxidants in living organisms. The process of cellular GSH reduction is not fully known yet. Oxidative stress can be a possible cause underlying that phenomenon, possibly dependent on the presence of even small quantities of aluminum and/or iron ions. ${ }^{23,29}$

The results of laboratory experiments should not be directly extrapolated to clinical conditions. According to many authors, during tooth tissue reconstruction, the thickness and permeability of dentine remaining in the cavity should also be considered ${ }^{30}$ Forming a partial barrier, it can reduce the cytotoxic potential of the materials by limiting the availability of water required for hydrolysis of the released components (reduced diffusion) and buffering capacity of hydroxyapatites.

Our research indicates that although the studied materials may belong to the same group, they are characterized by low, yet not uniform, cytotoxicity. This is probably related to differences in their chemical composition, which remains a trade secret of the manufacturers.

\section{Conclusions}

It seems fair to conclude that a toxic effect should not be assigned to a relevant group of materials, but each dentistry product should be evaluated individually.

\section{References}

1. Tillberg A, Järvholm B, Berglund A. Risks with dental materials. Dent Mater. 2008;24:940-943.

2. Murray PE, Garcia Godoy C, Garcia Godoy F. How is the biocompatibility of dental biomaterials evaluated? Med Oral Patol Oral Cir Bucal. 2007;12:E258-266.

3. Wataha JC. Principles of biocompatibility for dental practitioners. J Prosthet Dent. 2001;86:203-209.

4. Schmalz G. Concepts in biocompatibility testing of dental restorative materials. Clin Oral Invest. 1997;1:154-162.

5. Mount GJ. Clinical performance of glass-ionomers. Biomaterials. 1998;19:573-579.

6. Tyas MJ, Burrow MF. Adhesive restorative materials: A review. Austr Dent J. 2004;49:112-121.

7. Davidson CL. Advances in glass-ionomer cements. J Appl Oral Sci. 2006;14:3-9.

8. Mickenautsch S, Mount G, Yengopal V. Therapeutic effect of glassionomers: An overview of evidence. Austr Dent J. 2011;56:10-15.

9. Dos Santos RL, De Carvalho FG, Guênes GMT, Alves PM, Pithon MM. Histological analysis of biocompatibility of ionomer cements with an acid-base reaction. Braz Oral Res. 2014;28:1-7.

10. Lan WH, Lan WC, Wang TM, et al. Cytotoxicity of conventional and modified glass ionomer cements. Oper Dent. 2003;28:251-259.

11. De Souza Costa CA, Hebling J, Garcia-Godoy F, Hanks CT. In vitro cytotoxicity of five glass-ionomer cements. Biomaterials. 2003;24:3853-3858.

12. Hany Mohamed AA, Nor Shamsuria O, Norhayati L, Rajan S, Deepti S. Cytotoxicity evaluation of a new fast set highly viscous conventional glass ionomer cement with L929 fibroblast cell line. J Conserv Dent. 2011;14:406-408.

13. Kilic D, Kesim S, Liman N, Sumer Z, Ozturk A. In vitro comparison of the effects of dental filling materials on mouse fibroblasts. Biotechnol \& Biotechnol Eq. 2012;26:3155-3162.
14. Milhem MM, Al-Hiyasat AS, Darmani H. Toxicity testing of restorative dental materials using brine shrimp larvae (Artemia salina). J Appl Oral Sci. 2008;16:297-301.

15. Stanislawski L, Soheili-Majd E, Perianin A, Goldberg M. Dental restorative biomaterials induce glutathione depletion in cultured human gingival fibroblast: Protective effect of $\mathrm{N}$-acetyl cysteine. J Biomed Mater Res. 2000;51:469-474.

16. Schedle A, Franz A, Rausch-Fan X, et al. Cytotoxic effects of dental composites, adhesive substances, compomers and cements. Dent Mater. 1998;14:429-440.

17. Schmid-Schwap M, Franz A, König F, et al. Cytotoxicity of four categories of dental cements. Dent Mater. 2009;25:360-368.

18. Souza PP, Aranha AM, Hebling J, Giro EM, de Souza Costa CA. In vitro cytotoxicity and in vivo biocompatibility of contemporary resinmodified glass-ionomer cements. Dent Mater. 2006;22:838-844.

19. Da Silva EJ, Santos CC, Zaia AA. Long-term cytotoxic effects of contemporary root canal sealers. J Appl Oral Sci. 2013;21:43-47.

20. Geursten W. Biocompatibility of resin-modified filling materials. Crit Rev Oral Biol Med. 2000;11:333-355.

21. Consiglio R, Rengo $S$, Liguoro $D$, et al. Inhibition by glass-ionomer cements of protein synthesis by human gingival fibroblasts in continuous culture. Arch Oral Biol. 1998;43:65-71.

22. Lewis J, Nix L, Schuster G, Levebvre C, Knoernschild K, Caughman $\mathrm{G}$. Response of oral mucosal cells to glass ionomer cements. Biomaterials. 1996;17:1115-1120.

23. Stanislawski L, Daniau X, Lautié A, Goldberg M. Factors responsible for pulp cell cytotoxicity induced by resin-modified glass ionomer cements. J Biomed Mater Res. 1999;48:277-288.

24. Kan KC, Messer LB, Messer HH. Variability in cytotoxicity and fluoride release of resin-modified glass-ionomer cements. J Dent Res. 1997;76:1502-1507.

25. Wilson AD, Groffman DM, Kuhn AT. The release of fluoride and other chemical species from a glass-ionomer cement. Biomaterials. 1985;6:431-433.

26. Nicholson JW, Czarnecka B, Limanowska-Shaw H. Buffering and ion-release by glass-ionomer cement under near-neutral and acidic conditions. Biomaterials. 2002;23:2783-2788.

27. Nicholson JW, Czarnecka B. Review paper: Role of aluminum in glass-ionomer dental cements and its biological effects. J Biomater Appl. 2009;24:293-308.

28. Forss $H$. Release of fluoride and other elements from lightcured glass-ionomer in neutral and acidic conditions. J Dent Res. 1993;72:1257-1262.

29. Soheili Majd E, Goldberg M, Stanislawski L. In vitro effects of ascorbate and Trolox on the biocompatibility of dental restorative materials. Biomaterials. 2003;24:3-9.

30. Hamid A, Hume WR. The effect of dentine thickness on diffusion of resin monomers in vitro. J Oral Rehab. 1997;24:20-25. 